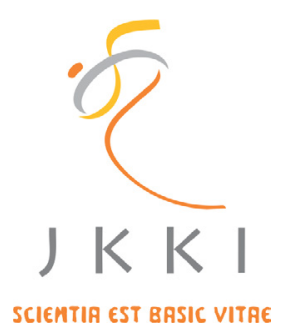

Jurnal Kedokteran dan Kesehatan Indonesia

Indonesian Journal of Medicine and Health

Journal homepage : www.journal.uii.ac.id/index.php/JKKI

\title{
Characteristics of children with secondhand smoking
}

\author{
Septian Emma Dwi Jatmika*1, Muchsin Maulana ${ }^{1}$ \\ ${ }^{1}$ Faculty of Public Health,Ahmad Dahlan University, Yogyakarta, Indonesia
}

Original Article

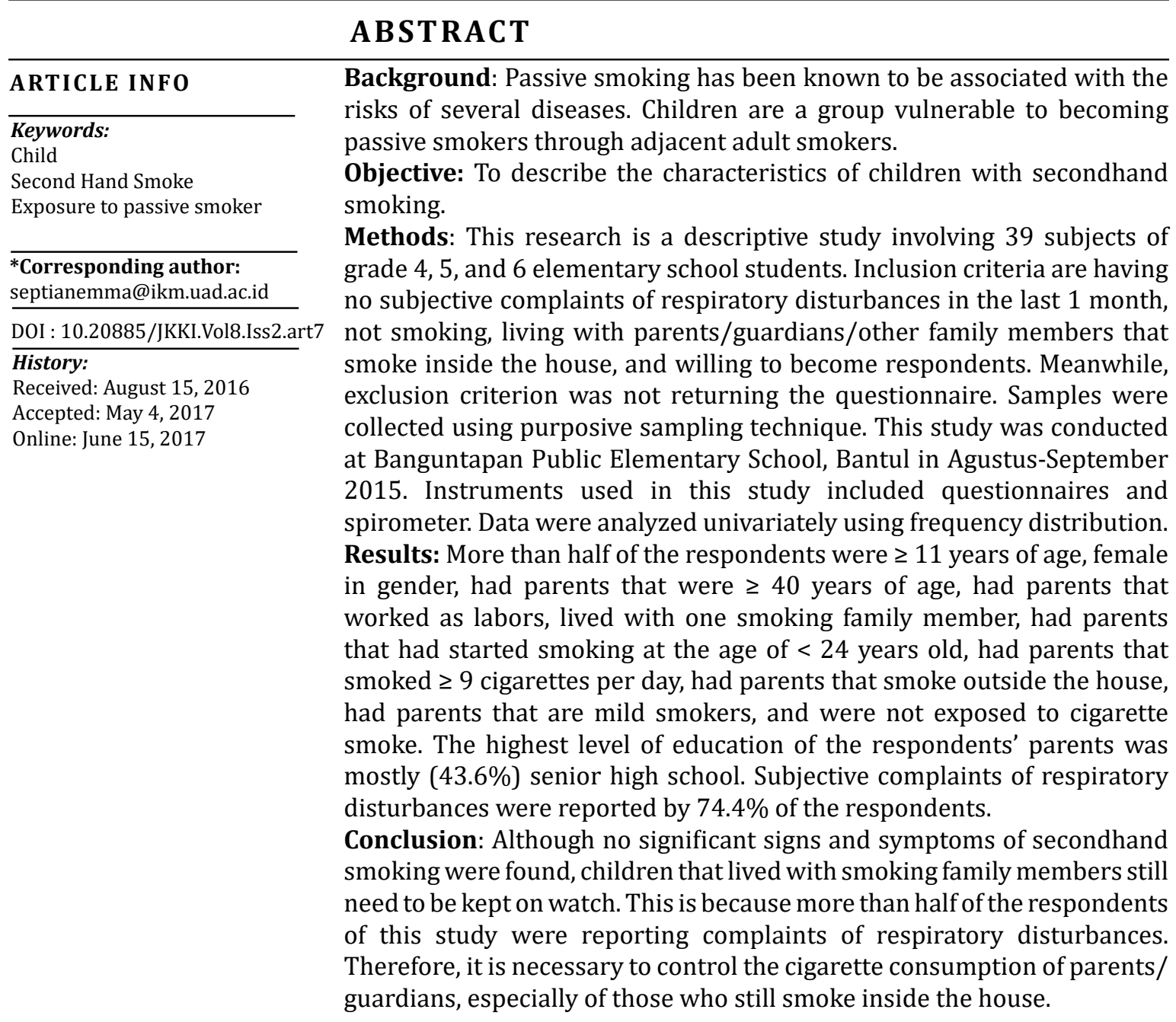

Latar Belakang: Perokok pasif telah diketahui berhubungan dengan risiko beberapa penyakit. Anak-anak merupakan kelompok yang rentan menjadi perokok pasif dari perokok dewasa disekitarnya. Tujuan: Untuk mendeskripsikan karakteristik anak dengan secondhand smoke.

Metode: Penelitian deskriptif dengan jumlah subyek 39 murid SD kelas 4, 5 dan 6. Kriteria inklusi penelitian meliputi tidak memiliki keluhan gangguan pernafasan dalam 1 bulan terakhir, tidak merokok, 
tinggal bersama orangtua/wali/anggota keluarga lain yang merokok di dalam rumah dan bersedia menjadi responden. Sedangkan kriteria ekslusi penelitian adalah kuesioner tidak kembali. Sampel diambil dengan menggunakan teknik purposive sampling. Penelitian dilakukan di SD Negeri Banguntapan, Bantul pada bulan Agustus - September 2015. Instrumen yang digunakan dalam penelitian ini antara lain kuesioner, dan spirometri. Analisis data dilakukan secara univariat (distribusi frekuensi).

Hasil: Separuh lebih responden berusia $\geq 11$ tahun, berjenis kelamin perempuan, orangtua berusia $\geq 40$ tahun, pekerjaan orangtua adalah buruh, anggota keluarga yang merokok adalah satu orang, orangtua/wali mulai merokok pada usia $<24$ tahun, orangtua/wali responden merokok $\geq 9$ batang/hari, orangtua/wali responden merokok di luar rumah, orang tua tipe perokok ringan dan responden tidak terpapar asap rokok. Tingkat pendidikan orangtua responden sebesar 43,6\% adalah tamat SLTA. Berdasaran hasil spirometri, $74,4 \%$ responden mengalami keluhan gangguan saluran nafas.

Kesimpulan: Meskipun belum ada tanda dan gejala second hand smoke yang signifikan, anak yang tinggal bersama anggota keluarga yang merokok tetap harus diperhatikan. Hal ini dikarenakan separuh lebih responden mengalami keluhan gangguan saluran nafas. Dengan demikian perlu adanya pengendalian jumlah konsumsi rokok pada orangtua/wali terutama yang merokok di dalam rumah.

\section{INTRODUCTION}

Cigarette smoke contains around 500 harmful gas particles, including tar and nicotine. Passive smokers will sustain the various effects of secondhand smoking on their health. Reports from health ministry of the United States show that children and women are the groups with the highest risk of developing disorders caused by cigarette smoke. ${ }^{1}$ Children, infants, and elderlies spend more time staying indoor. ${ }^{2}$ In children, the effects of cigarettes are more severe due to their immature immune system, as well as their narrower respiratory tract diameter that allows the amount of cigarette smoke entering their respiratory tract to be greater than their body weight. ${ }^{3}$

A result achieved in 2011, which gives the lowest contribution and still presents as a health problem, in general, was not smoking inside the house, reaching only a percentage of $46.67 \%$. Results of Basic Health Research (Riskesdas) 2010 showed that the prevalence of smokers in the Special Region of Yogyakarta (DIY) was $31.6 \%$ with $66.1 \%$ still smoking inside the house. The percentage of non-smoking households in DIY in 2012 was only $44.6 \%{ }^{4}$

Results of the preliminary survey conducted in June 2014 in District Banguntapan on 450 respondents showed that there are $50.89 \%$ of active smokers with $25.56 \%$ still smoking inside the house. Research on exposure to secondhand smoke on passive smokers is necessary in order to minimize the impact of secondhand smoke in passive smokers, especially children. Therefore, it became our interest to conduct a descriptive study on the characteristic of children with secondhand smoking.

\section{METHODS}

This research is a descriptive study with cross-sectional approach. Samples of the study were all grade 4, 5, and 6 elementary students with active smoker parents/guardians that met the inclusion and exclusion criteria of the study. These samples were collected using purposive sampling technique. The inclusion criteria of this study are: having no subjective complaints of respiratory disturbances in the last 1 month, not smoking, living with parents/guardians/ other family members that smoke inside the house, and willing to become respondents. The exclusion criterion of the study was not returning the questionnaire.

The number of samples obtained was 39 students. The study was conducted at Banguntapan Public Elementary School (SD Negeri Banguntapan), Bantul in AugustSeptember 2015. Instruments used in this study included questionnaires, weighing scales, microtoise, and spirometer. Data were analyzed univariately using frequency distribution. 


\section{RESULTS}

Baseline Characteristics of the
Respondents

As presented in Table 1, more than half of the respondents $(56.4 \%)$ were $\geq 11$ years of age and more than half of them $(64.1 \%)$ were female in gender.

Table 1. Distribution of Baseline Characteristics of the Respondents

\begin{tabular}{lll}
\hline Characteristic & n & \% \\
\hline Age & & \\
$\quad<11$ years old & 17 & 43.6 \\
$\quad \geq 11$ years old & 22 & 56.4 \\
Gender & & \\
$\quad$ Male & 14 & 35.9 \\
Female & 25 & 64.1 \\
\hline
\end{tabular}

Baseline Characteristics of the Parents of the Respondents

As presented in Table 2, more than half of the parents of the respondents (64.1\%) were $\geq 40$ years of age. Highest level of education of these parents was mostly senior high school (43.6\%). More than half of these parents (59\%) worked as labors.

Table 2. Distribution of Baseline Characteristics of the Respondents' Parents

\begin{tabular}{lcc}
\hline Characteristics & n & \% \\
\hline Ages & & \\
$\quad$ < 40 years old & 14 & 35.9 \\
$\geq 40$ years old & 25 & 64.1 \\
Level of Education & & \\
Not completed elementary school & 1 & 2.6 \\
Completed elementary school & 8 & 20.5 \\
Junior high school & 12 & 30.8 \\
Senior high school & 17 & 43.6 \\
Academy/university & 1 & 2.6 \\
Occupation & & \\
Labor & 23 & 59.0 \\
Government employee/national & 1 & 2.6 \\
army & 5 & 12.8 \\
Private employee & 8 & 20.5 \\
Merchant/entrepreneur & 2 & 5.1 \\
Others & &
\end{tabular}

Distribution of the Number of Smoking Family Member in the Respondents' Households

As presented in Table 3, the number of smoking family member in the respondents' households was mostly one person (82.05\%).

Tabel 3. Distribution of the number of Smoking Family Member

\begin{tabular}{ccc}
\hline $\begin{array}{c}\text { Number of Smoking } \\
\text { Family Member }\end{array}$ & $\mathbf{n}$ & $\mathbf{\%}$ \\
\hline 1 & 32 & 82.05 \\
2 & 5 & 12.83 \\
3 & 1 & 2.56 \\
4 & 1 & 2.56 \\
\hline
\end{tabular}

Determinants of Smoking Behavior in the Parents/Guardians of the Respondents

As presented in Table 4, more than half of the parents/guardians of the respondents (56.4\%) had started smoking every day at the age of < 24 years old. More than half of these parents/ guardians (51.3\%) had smoked for the first time at the age of $\geq 20$ years old. More than half of these parents/guardians (53.8\%) smoked $\geq 9$ cigarettes per day. More than half of these parents/guardians (64.1\%) smoked outside the house. More than half of these parents/guardians (66.7\%) were mild smokers.

\section{Distribution of Cigarette Smoke Exposure Rate to the Respondents}

As presented in Table 5, most respondents (87.2\%) were not exposed to cigarette smoke.

\section{Distribution of Respondents' Complaints of Respiratory Disturbances}

As presented in Table 6, more than half of the respondents $(74.4 \%)$ were experiencing complaints of respiratory disturbances.

\section{Distribution of the Results of Respondents' Pulmonary Function Test}

As presented in Table 7, all respondents were showing normal pulmonary function. 
Tabel 4. Determinants of Smoking Behavior in the Parents/Guardians of the Respondents

\begin{tabular}{lcc}
\hline Determinants of Smoking Behavior & n & \% \\
\hline Age of starting to smoke every day & & \\
$\quad$ < 24 years old & 22 & 56.4 \\
$\quad \geq 24$ years old & 17 & 43.6 \\
Age of smoking for the first time & 19 & 48.7 \\
$\quad$ < 20 years old & 20 & 51.3 \\
$\quad \geq 20$ years old & & \\
Number of cigarettes/day & 18 & 46.2 \\
$\quad$ < 9 cigarettes/day & 21 & 53.8 \\
$\quad \geq 9$ cigarettes/day & & \\
Place to smoke & 10 & 25.6 \\
Inside the house & 25 & 64.1 \\
$\quad$ Outside the house & 4 & 10.3 \\
Near other family member & & \\
Type of Smoker & 26 & 66.7 \\
Mild smoker & 11 & 28.2 \\
Moderate smoker & 2 & 5.1 \\
Heavy smoker & & \\
\hline
\end{tabular}

Table 5. Distribution of Cigarette Smoke Exposure Rate to the Respondents

\begin{tabular}{lll}
\hline Cigarette Smoke Exposure Rate & n & \% \\
\hline Exposed & 5 & 12.8 \\
Not exposed & 34 & 87.2 \\
\hline
\end{tabular}

Table 6. Distribution of Respondents' Complaints of Respiratory Disturbances

\begin{tabular}{lll}
\hline Complaints & n & \% \\
\hline Not present & 10 & 25.6 \\
Present & 29 & 74.4 \\
\hline
\end{tabular}

Tabel 7. Distribution of the Results of Respondents' Pulmonary Function Test

\begin{tabular}{lll}
\hline Pulmonary Function & n & \% \\
\hline Normal & 39 & 100 \\
Abnormal & 0 & 0 \\
\hline
\end{tabular}

\section{DISCUSSIONS}

The effect of secondhand smoking in children can be determined by measuring their lung function using spirometry. ${ }^{5,6}$ Measurement of lung function on all respondents showed normal results. Although there had been no significant signs and symptoms, children living with smoking family members should still be kept on watch. This is because despite being a non-smoker, exposure to secondhand smoke will allow them to inhale nicotine and other toxic substances contained in cigarette smoke. Nicotine can still be found in the body of a nonsmoker if the person inhales secondhand smoke. ${ }^{7}$

The results of this study cannot be analyzed using bivariate analysis. This is because the pulmonary function test was showing normal measurements in all respondents. There are several possibilities that could cause this, including Firstly, measurement of lung function that was less than optimal. While the measurement of pulmonary function using spirometry can basically be performed on children, it will give optimal results when performed on respondents at the age of 17 years or older. This is because the cooperativeness of the respondents to follow the instructions from the officers during the implementation of the pulmonary function test was fundamental to maintain its validity. Secondly, the number of 
samples obtained is too little: only 39 children. The collection of these samples were performed using purposive sampling technique. Upon initial sampling, data from 66 children were included, but on initial data collection using questionnaires, some of these children returned incomplete questionnaires or did not return the questionnaires at all or when questionnaires were taken, the respondents were absent. The number of questionnaires returned at this point was 46 . Furthermore, on the second data collection which was the measurement of pulmonary function using spirometry, one child was absent while 6 children failed to follow the instructions for the measurement. Therefore, the total number of respondents remained was 39 children.

Evaluation of cigarette smoke exposure rate to the respondents showed that more than half of them $(87.2 \%)$ were not exposed to cigarette smoke. Nevertheless, $74.4 \%$ of these respondents subjectively reported mild respiratory complaints, such as a cough, runny nose, and shortness of breath in the last 1 month. Children who lived with smoking parents/guardians and were exposed to cigarette smoke still need to be kept on watch even though their percentage was small. Cigarette smoke can inflict damage to ciliated epithelial tissue, decrease mucociliary clearance, and suppress phagocytic activity and bactericide effect of alveoli macrophages that may result in bronchial hyperreactivity. ${ }^{8}$ The previous study has shown that the incidence of acute respiratory infection (ARI) in toddlers has a significant association with parental smoking habit inside the house. ${ }^{9}$

According to the results of this study, most respondents (82.5\%) were found to be living together with one smoking family member, while a small number of these respondents (2.56\%) were living with as many as four smoking family members. The habit of smoking inside the house affects other family members who do not smoke. The results also showed that family members who smoke inside the house could still be found in $25.6 \%$ of the data while some were even smoking near other family members in $10.3 \%$ of the data. Cigarette smoke is very harmful to health, especially for toddlers due to the toxic substances contained in cigarettes. ${ }^{10}$ Children under five living together with family members who smoke are 4.56 times more likely to suffer from ARI 4.65 than toddlers who live with family members that are not smoking. ${ }^{2}$ Lower respiratory tract infections are more common in smokers and passive smokers, especially infants and children. ${ }^{11}$

Exposure to people who do not smoke (passive smoking) is only associated with an increased risk of acute respiratory illness in the first 2 years of life. Exposure from maternal smoking multiplies the risk of lower respiratory tract disease in the first 2 years of a toddler's life by about 2 times. ${ }^{12}$ Although this study showed that the pulmonary function in all respondents was normal, subjective complaints of mild respiratory disturbances, such as a cough, runny nose, and shortness of breath in the last 1 month were still reported by $74.4 \%$ of the respondents.

\section{CONCLUSIONS}

No significant signs and symptoms of secondhand smoking were found in children that lived with smoking family members as indicated by normal measurements of pulmonary function found in all respondents. However, more than half of these respondents were reporting subjective complaints of respiratory disturbances.

\section{RECOMMENDATIONS}

It is necessary to control the cigarette consumption of the parents/guardians, especially of those who still smoke inside the house.

\section{REFERENCES}

1. Rai IBN, Artana IGNB. Merokok dan ketergantungan nikotin pada penduduk Tenganan Pengrisingan, Karangasem, Bali. Jurnal Respirologi Indonesia. 2009;29(4).

2. Mukono HJ. Toksikologi lingkungan. Surabaya: Airlangga University Press; 2005.

3. Emilda R. Paparan asap rokok sebagai faktor risiko asma pada anak dengan rinitis alergika. Program Pascasarjana UGM; 
2014.

4. Kementerian Kesehatan Republik Indonesia. Riset kesehatan dasar. Kementerian Kesehatan Republik Indonesia 2010.

5. Eisner MD, Balmes J, Katz PP, Trupin L, Yelin EH, Blanc PD. Lifetime environmental tobacco smoke exposure and the risk of chronic obstructive pulmonary disease. Environmental Health. 2005;4:7.

6. Flouris AD, Metsios GS, Carrillo AE, Jamurtas AZ, Gourgoulianis K, Kiropoulos T, et al. Acute and short-term effects of secondhand smoke on lung function and cytokine production. American Journal of Respiratory and Critical Care Medicine. 2009;179(1):1029-33.

7. Okoli CTC, Kelly T, Hahn EJ. Secondhand smoke and nicotine exposure: A brief review. Addictive Behaviors. 2007;32(10):1977-88.

8. UKK Pulmonologi PP IDAI. Kartasasmita CB. Epidemiologi asma anak, in: Focus on asthma, Indonesian Pediatric Respiratory Meeting I/2003, 8-10 Agustus 2003. Jakarta; 2003.

9. Milo S, Ismanto AY, Kallo VD. Hubungan kebiasaan merokok di dalam rumah dengan kejadian ISPA pada anak umur 1-5 tahun di Puskesmas Sario Kota Manado. Jurnal Keperawatan. 2015;3(2).

10. Naria E, Chahaya I, Asmawati. 8 Hubungan kondisi rumah dengan keluhan ISPA pada balita di wilayah kerja Puskesmas Tuntungan, Kecamatan Medan Tuntungan tahun 2008. Universitas Sumatera Utara; 2008.

11. Corwin EJ. Buku saku patofisiologi. Jakarta: EGC; 2000.

12. Graham NM. The epidemiology of acute respiratory infections in children and adults: A global perspective. Epidemiologic Reviews. 1990;12:149-78. 